\section{Universal Banking, Control Rights, and Corporate Finance in Germany}

\author{
William R. Emmons and \\ Frank A. Schmid
}

orporate governance mechanisms assure investors in corporations that they will receive adequate returns on their investments (Shleifer and Vishny, 1997, p. 737). If these mechanisms did not exist or did not function properly, outside investors would not lend to firms or buy equity in them. Businesses would be forced to rely entirely on their own internally generated cash flows and accumulated financial resources to finance ongoing operations as well as profitable investment opportunities. Overall economic performance would suffer because many good business opportunities would be missed and temporary financial problems at individual firms would spread quickly to employees, consumers, and other firms.

Despite their universal importance and a considerable international exchange of ideas and institutions, corporate governance systems differ, even among advanced market economies. Useful generalizations can be drawn, however, and researchers commonly differentiate between two leading corporate governance systems (Shleifer and Vishny, 1997, p. 737): (1) the "AngloSaxon" model found in the United States, the United Kingdom, and other Englishspeaking countries, and (2) the "GermanJapanese" model found in the two countries named and, to varying degrees, in other countries that share historical or economic traditions with them. Two important dimensions along which these leading corporate governance systems differ are the role of financial markets and the influence of workers on corporate decision making.

Financial markets are important sources of corporate finance and corporate governance in countries operating under the Anglo-Saxon model. Public and private markets for debt and equity securities issued by corporations outstrip the amount of financing provided directly by financial intermediaries by a wide margin. Many firms change hands each year on the stock market, some without the consent of incumbent management (i.e., via hostile takeovers). M eanwhile, employees' influence on matters of corporate governance is very diffused, exercised primarily through union representation and a limited amount of equity ownership in pension or personal savings plans. Firms in which non-executive workers play a meaningful role in corporate decision making are the exception rather than the rule in these economies. ${ }^{1}$

Capital allocation and corporate governance practices in countries operating under the German-Japanese model differ substantially from practices in the AngloSaxon model. This article focuses on the German system in particular, in which universal banks are the primary source of corporate finance to firms of all sizes.? These banks lend directly to firms, take equity stakes under certain circumstances, and provide underwriting services to firms issuing debt or equity securities to the public market. Corporate debt and equity markets remain very small in relation to the size of the German economy. Corporate governance is dominated by universal banks and by nonbank block shareholders. Control changes (i.e., changes of management teams) tend to be arranged behind closed doors, often by the banks or other blockholders, rather than being carried out

\footnotetext{
${ }^{1}$ For surveys of corporate governance that focus on or include the United States, see J ensen (1993) or Shleifer and Vishny (1997).

2 See Shleifer and Vishny (1997) and the references therein for more information on the Japanese system of corporate governance.
} 
through a stock-market takeover. In stark contrast to the United States and other countries operating under the Anglo-Saxon model, there have been only a handful of hostile takeovers in Germany since World War II.

The other notable feature of the German system highlighted in this article is employees' significant direct influence on strategic corporate decision making. This role in corporate governance extends far beyond that conferred by union representation and employee stock ownership, the main channels of employee influence in the Anglo-Saxon model.

Theoretical analyses of the relative merits of the U.S. and German financial and corporate governance systems have begun to appear only recently; for example, see Hellwig (1991), Allen and Gale (1995), or Dietl (1998). We attempt to answer a much narrower set of questions in this article: What control mechanisms are present in Germany that do not operate in the U.S.? Why do the corporate governance systems of these two economically advanced countries differ so much? What empirical research has been done on the effects of control mechanisms on the performance of firms? Our hope is that by answering these questions we will help lay the groundwork for tackling the much more difficult questions related to welfare comparisons of different financial systems.

\section{OVERVIEW OF CORPORATE GOVERNANCE IN GERMANY}

The two most distinctive institutional features of corporate governance in Germany may be the extensive role of big universal banks and the strong influence of workers on corporate decision making. First, universal banks lend to firms, underwrite shares, hold equity positions, act as market makers at the stock exchange, ${ }^{3}$ sit on corporate boards, and exercise proxy votes for shares owned by others. Second, workers have a strong voice in corporate affairs, institutionalized by laws concerning Mitbestimmung, or codetermination. These laws guarantee workers a certain number of seats on corporate boards. In particular, every large German corporation must reserve 50 percent of the seats on its supervisory board (board of directors) for employee representatives. In a few cases, employee representatives also hold seats on a stock corporation's management board (committee of the top executives). The shaded insert on the next page describes the three forms of codetermination in Germany.

Universal banking and codetermination have common origins. Both are state or quasi-state institutional means of coordinating individual activities and achieving social consensus. Although both universal banking and codetermination have profound implications for the allocation of private control and property rights, only codetermination derives its legitimacy and concrete form from statute. The case of universal banks is more subtle. The major universal banks are privately owned, but they are sometimes described as quasi-state institutions. First, they are exempted from some forms of market discipline. In particular, they are widely perceived to be both "too big to fail" and "too important to be taken over" except with government approval (this special status of large banks is not unique to Germany, of course). Second, universal banks are expected (and commonly perceived) to act in the public and/or national interest rather than seeking strictly to maximize profits. In the words of an earlier British observer, "W hat the great public and semipublic institutions are to the French economy, the big banks are to Germany" (Shonfield, 1965, p. 247).

A recent corporate control contest in Germany brought into sharp relief just how different the German and AngloSaxon models of corporate governanceand public sensitivities about these differences - really are. During the spring of 1997, Fried. Krupp AG Hoesch-Krupp ("Krupp"), one of Germany's largest steel and engineering companies, launched a hostile takeover bid for Thyssen AG ("Thyssen"), its main competitor. The takeover attempt was financed by Deutsche 


\section{CODETERMINATION}

There are two major corporate forms in Germany: the Aktiengesellschaft (stock corporation), abbreviated AG, and the Gesel Ischaft mit beschränkter Haftung (Iimited-liability corporation), abbreviated $\mathrm{GmbH}$. Both types of corporation have limited liability, but a GmbH cannot be listed on a stock exchange. They are governed by a two-tier board system, comprising the supervisory board (Aufsichtsrat) and the management board (Vorstand).

Codetermination laws apply to all corporations in Germany with at least 500 employees. Codetermination rules cover the supervisory board, the functions of which are to control and monitor the management, to appoint and dismiss members of the management board, to fix their salaries, and to approve major decisions of the management board.

Although elements of codetermination were present in pre-war Germany, four laws have been passed in the postWorld War II period re-introducing codetermination. First, M ontanmitbestimmung (codetermination in the coal and steel industry) was introduced in 1951. This law, which remains the most far-reaching of all codetermination laws, mandated equal representation of employees and shareholders on the supervisory boards of firms operating in the coal and steel industry. Among other provisions, it specified that board members must elect a so-called neutral board member to break ties. This person is typically a prominent political or cultural figure. In addition, one member of the management board must represent workers' interests (Arbeitsdirektor). This person cannot be appointed over the objections of a majority of the employee representatives on the supervisory board.

The second important law concerning codetermination was the Betriebsverfassungsgesetz (Workplace Governance Act) of 1952. This act extended codetermination to all companies with limited liability. It did not replace M ontan- codetermination but, instead, modified it for application to other firms. One-third of the supervisory board seats in these enterprises were reserved for representatives of employees. Exceptions were granted for organizations with political, religious, media, or other character for which freedom of speech is central to their mission. In addition, stock corporations with fewer than 500 employees that are owned by a family are also exempted.

Third, M ontan-codetermination was extended to include more specific rules and procedures in 1956. This form of codetermination remains the most intrusive in terms of how it affects the corporate governance of the firm. Only 10 companies remained subject to Montancodetermination in 1997, compared to 49 in the 1960s.

Finally, under the Codetermination Act of 1976, any corporation that has more than 2,000 employees (and was not already covered by M ontan-codetermination) must allow employees to elect onehalf of the members of the supervisory board. This law preempts the 1952 law. Total board size is either 16,18 , or 20 members. At least one supervisory board member is a representative of the middle management (leitende Angestellte). If the supervisory board has 16 or 18 members, two of the worker representatives have to be labor union representatives. If the board consists of 20 members, there are three union representatives. The supervisory board chairman is effectively elected by the shareholders' representatives and is given an extra vote to break ties, so there is no need for a neutral member.

The laws governing stock corporations allow individual companies some leeway to determine which decisions must be approved by the supervisory board. However, some types of decisions must be ratified by the supervisory board. Thus, workers are guaranteed a significant voice in the process of corporate decision making in Germany. 
Morgan Grenfell and Kleinwort Benson, the London-based investment bank subsidiaries of Deutsche Bank and Dresdner Bank, respectively ( two of the three large private universal banks). The soon-to-be CEO of Deutsche Bank, Rolf Breuer, publicly likened this takeover battle to a test of whether Anglo-Saxon-style takeovers are feasible in Germany.

The public reaction was swift and unambiguously negative. Strikes and demonstrations of furious Thyssen workers followed the announcement of the bid. The conservative German chancellor, Helmut Kohl, expressed his "deep concern" over the matter and asked the parties to "live up to their social responsibilities." Public outrage culminated in a demonstration outside Deutsche Bank headquarters in Frankfurt, the largest bank in Germany and financial advisor to Krupp.

Bank leaders expressed frustration with what they called inconsistent public criticism. For years, the big German banks had been taken to task for hampering the development of capital markets that would function along the lines of British or American markets. Yet now, when they attempted to use German financial markets for one of its best-suited purposes- effecting a change in the ownership structure and the management team-they faced renewed criticism. If Germany is to have well-developed AngloSaxon-style capital markets, they argued, all parties must accept the proposition that a principal outcome of stock-market trading is to allow involuntary control changes. This mechanism enhances firm efficiency and is one of the most important contributions stock markets can make to overall economic efficiency (M anne, 1965). The shaded insert on the next page provides further details on this takeover battle.

\section{CULTURAL TRADITIONS: THE CONSENSUS MODEL}

To understand the important institutional features of corporate governance in Germany, and to appreciate how different they are from the Anglo-Saxon tradition, we must take a look back into the intellectual histories of Germany and the U nited Kingdom. While there are certainly similarities among all versions of capitalism, it appears reasonable to speak of a distinctive continental European model of capitalism stressing social consensus. It differs from the Anglo-Saxon model most fundamentally with regard to the role of the state in the economy and the social safety net. And, as we have noted, workers' rights could be added to this list of differences.

In Wealth of Nations (1776), Adam Smith (1723-90) argued in favor of a society based on individual decision making which, coordinated by the invisible hand, would ensure the social optimum. Smith saw little need for central government planning:

The sovereign is completely discharged from a duty, in the attempting to perform which he must always be exposed to innumerable delusions, and for the proper performance of which no human wisdom or knowledge could ever be sufficient; the duty of superintending the industry of private people, and of directing it towards the employments most suitable to the interest of the society. (Book 4, Chapter 9).

Although his writings circulated in Germany, Smith's world view never became as influential there as in the Anglo-Saxon countries. Instead, Germans (as well as most other continental Europeans) have been influenced more strongly by the German philosopher, G.F.W. Hegel (1770-1831) and his most well-known follower, Karl Marx (1818-83).

In Philosophy of Right (1821), Hegel agreed with Smith that markets turn "subjective selfishness into a contribution towards the satisfaction of the need of everyone else." In contrast to Smith, however, Hegel was pessimistic about some aspects of the outcome of unfettered market operations. Hegel predicted that unrestrained market exchanges would produce a class caught in a spiral of poverty. Hegel called for a system of social contracts that would complement individuals' market transactions by collective bargaining arrangements and elements of central planning. As the provider of such 


\section{THE THYSSEN-KRUPP MERGER}

At the beginning of 1997, Fried. Krupp AG Hoesch-Krupp ("Krupp") and Thyssen AG ("Thyssen") were two of the largest German steel and engineering companies. Krupp was somewhat smaller than Thyssen, with total assets of DM 17.8 bn (end-offiscal year 1996) versus DM 25.5 bn for Thyssen (end-of-fiscal year 1995/96). In terms of European industry rankings, Thyssen was the $149^{\text {th }}$ largest firm in Europe and Krupp ranked as number 273 (Financial Times, 1998).

The two firms had always been similar in some respects. Since World War II, both companies had acquired many other German steel makers to expand their steel-making capacity. Both firms had transformed their steel divisions into subsidiaries (Krupp Stahl and Thyssen Stahl) to facilitate diversification by the parent company. Finally, both firms had focused their recent acquisitions on engineering.

In 1991, CEO Gerhard Cromme announced Krupp's desire to enter into a close alliance with Hoesch AG. Krupp backed up Cromme's ambition by acquiring a 24.9 percent equity stake in Hoesch. This position had been built up in the course of the year with the help of a Swiss bank. It had remained unnoticed until Cromme's announcement because the threshold for mandatory public disclosure of block holdings in Germany was 25 percent at that time (it was changed to 5 percent in 1995; it is also 5 percent in the United States). Deutsche Bank had installed Kajo Neukirchen as CEO of Hoesch just a few months earlier and was caught by surprise when Krupp announced its intentions. Despite a 15 percent voting restriction (ceiling) imposed on any shareholder by Hoesch's corporate bylaws, Krupp overcame vigorous resistance by N eukirchen and merged with Hoesch in 1992.

For several years in the early 1990s, Gerhard Cromme had tried to find a way to merge Krupp and Thyssen. However, Cromme was never able to make any headway with Thyssen's CEO, Dieter Vogel. In the end, Krupp enlisted Deutsche Bank for a takeover attempt. The takeover strategy itself was developed by Goldman Sachs of the United States and bore the telling code name "Hammer und Thor." Financing was arranged by Deutsche Morgan Grenfell and Kleinwort Benson, London-based investment bank subsidiaries of Deutsche Bank and Dresdner Bank, respectively.

On March 17, 1997, rumors spread that Krupp would launch a takeover attack on Thyssen. The next day, Krupp made its intentions public, announcing a tender offer for Thyssen. Krupp and Thyssen shares were suspended from stock exchange trading as details were communicated to the market. Thyssen made clear that it did not welcome the bid and considered the takeover attempt hostile. Infuriated Thyssen workers demonstrated in front of the Krupp headquarters.

In response to public outrage and strikes at Thyssen's steel subsidiary, the state government of N orth Rhine-Westfalia, home of both companies, offered to act as a mediator. The state prime minister met with the CEOs of both companies on $M$ arch 18. He convinced them to consider a merger of the steel subsidiaries alone, rather than of the entire enterprises. In deference to these talks, Krupp suspended its takeover bid for a week. On March 24, Krupp and its banks withdrew the bid. N egotiations over a merger of the steel subsidiaries continued.

At the end of March, Krupp and Thyssen announced the merger of their steel subsidiaries into Thyssen Krupp Stahl AG, to become effective April 1. This company is now the largest steel maker in Europe and the thirdlargest in the world.

In August of 1997, the public learned that there had been more confidential talks about a complete merger of Krupp and Thyssen. In mid-September, the surprising results of these talks emerged. The 
management boards of both firms had agreed to a complete merger. The proposed merger received the approval of the supervisory boards of Thyssen (on January 22, 1998) and of Krupp (on February 5,1998 ) with thin majorities.

Sorting out the details of this merger will not be simple. Thyssen was subject to M ontan-codetermination rules (i.e., specific to the coal and steel industries and more favorable to union representatives), while Krupp was subject to the regular form of equal representation (with a lesser role for trade unions). All 10 worker representatives on the Thyssen supervisory board voted against the merger, and the so-called "neutral member" of the board broke the tie in favor of merging. On the Krupp supervisory board, the representative of middle management voted in favor of the merger. Otherwise, the vote would have been deadlocked and the chairman would have been forced to use his second vote to break the tie. The new firm, Thyssen-Krupp AG, is not subject to M ontan-codetermination and its strong trade-union influence. This may be one of the reasons why Thyssen's unionized workers resisted the merger so strongly.
The roles played by Deutsche Bank and Dresdner Bank in this takeover battle remain controversial in Germany. When Krupp launched its takeover attempt with the backing of the banks, Wolfgang Röller, the ex-CEO of Dresdner Bank and current chairman of its supervisory board, was a member of Thyssen's supervisory board. When his board term ended at the end of March 1997, he was succeeded by Bernhard Walter, a member of the Dresdner Bank management board (and now its (EO). Even more delicate was the case of Ulrich Cartellieri, a member of the management board of Deutsche Bank and simultaneously a member of the Thyssen supervisory board. As a member of Thyssen's supervisory board, he had access to inside information that would have been valuable to Krupp, Deutsche Bank's client. As a member of the Deutsche Bank management board, he approved the takeover attempt. Haunted by sharp public criticism, Cartellieri retired from both positions on May 20, 1997.

SOURCE: Various issues of "Die Welt," German Daily, বttp:// www.welt.de>; Frankfurter Allgemeine Zeitung (March 18, 1998). a framework, the State should be a means toward the manifestation of the "common will." The principle underlying all of the institutions envisioned by Hegel - and rejected by Smith - is that the market should be guided and controlled to ensure that every individual is treated fairly in his or her transactions with "society as a whole." Building on Hegel's distrust of the market, Marx proposed reorganizing society to do away with markets altogether.

Hegel's ideas continue to influence thinking in Germany to this day (although Marxian radicalism is clearly in eclipse). The Hegelian concept of a market economy with a social component is enshrined in the modern German constitution, which proclaims that the Federal Republic is to be a Soziale M arktwirtschaft, or "social market economy." Market mechanisms are often viewed with suspicion in Germany, their results being regarded as chaotic, risky, and unfair. As a result, numerous social contracts, such as the state-run, pay-as-you-go pension system, generous unemployment and disability insurance, and collective industry-wide wage agreements, substitute for or complement market outcomes. These social contracts coordinate individual activities toward the "common will" and reduce individuals' idiosyncratic risks.

Hegel's influence extends to contemporary business practices in Germany. Writing in a survey of corporate control in Germany, Ellen Schneider-Lenné (1992) - who, until her early death in 1996, was a member of the management board of Deutsche Bankdescribes the appropriate objectives of a German firm such as Deutsche Bank: 
The objectives of German companies, however, do not stop at maximization of the return on investment. Their philosophy is based on the concept of the interest of the company as a whole,' a key concept of German corporate culture.

The company is seen as a combination of various groups whose goals have to be coordinated. The company's prime objective is doubtless to secure the survival over the long term. Alongside this, however, the long-term interests of its employees, customers, suppliers, and the general public have also to be taken into consideration. The creation and maintenance of jobs with attractive working conditions has special priority. There is also a growing sense of responsibility towards the environment. In Germany the enterprise is considered to be embedded in society, and since it profits from society it also has obligations towards it. This commitment is rooted in the German constitution which says that ownership entails obligations.

The widely varying conflicts of interest that can arise between individual groups within the company and outside are usually resolved by compromise. One might, therefore, call it a 'consensus model' (pp. 15-16).

\section{THE INSTITUTIONAL FRAMEWORK FOR CORPORATE CONTROL SYSTEMS IN GERMANY}

This section provides an overview of the institutional framework within which internal and external control mechanisms are exercised in Germany. Internal control mechanisms include a firm's bylaws and the powers exercised by shareholders at the annual meeting, as well as the two-tier board system that is designed to guide the firm on a daily basis and to provide an early-warning system when problems and threats arise. External control mechanisms include product-market competition, political, legal, and regulatory controls, and the capital markets, primarily the stock market. Large-block shareholders

\section{Table 1}

Votes Cast at Annual Shareholder Meetings as a Percentage of Shares Outstanding

\begin{tabular}{|c|c|c|c|c|c|}
\hline Company & 1975 & 1980 & 1986 & 1990 & 1994 \\
\hline BASF & 65.9 & 66.2 & 55.4 & 52.4 & 50.9 \\
\hline Bayer & 64.9 & 67.5 & 52.9 & 47.2 & 48.4 \\
\hline Continental & 72.9 & 65.0 & 35.1 & 58.7 & 47.3 \\
\hline Daimler-Benz & 93.0 & 89.7 & 80.4 & 78.6 & 70.8 \\
\hline Hoechst & 69.6 & 66.7 & 58.3 & 66.9 & 71.5 \\
\hline Mannesmann & 65.1 & 63.4 & 49.6 & 37.0 & 45.7 \\
\hline Schering & 47.1 & 58.0 & 46.6 & 33.7 & 36.7 \\
\hline Siemens & 72.1 & 72.1 & 58.2 & 49.5 & 53.9 \\
\hline Thyssen & 84.0 & 79.0 & 68.5 & 64.8 & 68.3 \\
\hline VEBA & 80.9 & 78.3 & 65.2 & 51.1 & 46.2 \\
\hline Volkswagen & 58.6 & 59.9 & 50.1 & 34.7 & 32.9 \\
\hline
\end{tabular}

SOURCE: Bundesverband deutscher Banken <http:/ / www.bdb.de>.

and universal banks are the two most prominent stakeholder groups that effectively span the internal and external control environments. The next section of this article examines how these key stakeholders perform their corporate governance functions.

\section{Internal Control Systems: Annual Shareholder Meetings}

The most basic internal control mechanism of any publicly traded firm is the annual shareholder meeting. This is the only occasion on which the management team is obliged to listen to shareholders' views and to answer their questions. However, very few small shareholders vote at annual meetings, calling into question the ability of this control mechanism to provide appropriate governance of corporate decisions. Table 1 shows that shareholder representation at annual meetings of large firms with dispersed ownership is low and declining. For example, the fraction of outstanding shares actually voted at the 1994 annual meeting of Schering, a pharmaceutical company without a large blockholder, was a mere 36.7 percent.

The most important outcome of the annual shareholder meeting is the election of supervisory board members, who function as the shareholders' representatives 
throughout the rest of the year. Other important issues considered at this time include the possibility of offering new shares for sale as well as what fraction of the year's profit to retain and what fraction to pay out as dividends.

Shareholders in Germany who do not plan to attend the annual meeting are allowed to transfer their voting rights to someone else, either a person or an institution. Small shareholders and blockholders alike make use of this right to designate a proxy (a "stand-in") to vote their shares. Blocks held by individuals are frequently voted by bank executive directors or other trusted individuals. Also, some blocks owned by foreign governments are voted regularly by German banks. Most small shareholders who bother to vote designate either a bank or a shareholder association (an organization pledging to safeguard small shareholders' interests) to be their proxy.

Legally, shareholders may transfer their voting rights to any person or institution. Universal banks have a competitive advantage over other parties in obtaining proxy voting powers, however, because universal banks provide the vast majority of retail brokerage services in Germany, and most equity shares are in bearer form (i.e., anonymous as opposed to being registered with the company issuing them, as in the United States). Shareholders typically need custodial services to safeguard their shares, and custody is a basic banking business. It is a small step in the minds of most retail shareholders to transfer their voting rights to the bank that holds their shares. The banks also have an informational advantage by knowing who owns the shares.

Authority for bank-proxy voting must be granted by shareholders in writing and must be renewed at least once every 15 months. Shareholders may revoke their prior authorization at any time, in writing. The bank must mail the upcoming agenda to shareholders in advance of the annual meeting, indicating how the votes will be cast unless otherwise instructed by the shares' owner. Unless a shareholder replies with explicit voting instructions, the bank votes the shares as it previously indicated it would. ${ }^{4}$ In the experience of Bayerische Hypotheken- und Wechsel-Bank during 1973, only 350 out of 300,000 ( 0.1 percent) of the shareholders who used bank-proxy voting gave the bank alternate instructions (Die Aktiengesel Ischaft, Nr. 2 / 1974, p. 59).

Proxy voting by banks was criticized severely by a government antitrust commission when it examined competition in the German economy (M onopolkommission, 1978). The commission determined that, at the 1975 annual meetings of 56 of the 100 largest stock corporations, banks exercised at least 5 percent of the votes (M onopolkommission, 1978). About 50 percent of these votes were proxy votes. In 30 of the meetings, banks cast more than 50 percent of the votes, comprising their own shares and the proxy votes they exercised; in 11 cases, they cast between 25 percent and 50 percent of the votes; and in 15 cases, between 5 percent and 25 percent of the votes. Similarly, Böhm (1992) confirms that banks (primarily the three largest private universal banks, Deutsche, Dresdner, and Commerzbank) dominated many shareholder meetings in 1986.

Voting patterns at the annual meetings of the banks themselves epitomize the danger that proxy voting may create disenfranchised shareholders. Analyzing data from 1986 shareholder meetings, Gottschalk (1988) reports that if the three large universal banks had voted together as a blockincluding both their own shares and the shares they voted in proxy - they would have commanded a majority of the votes at each bank's annual meeting. This was true despite the fact that none of the banks itself owned more than a trivial amount of shares in either of the other two. It should also be noted that the banks do not actively compete for proxy votes; these are merely a byproduct of their large branch and retail brokerage networks.

A proposed change in legislation (pending at the time this article was written) would restrict banks' use of proxy votes to firms in which the banks hold at least 
5 percent of the voting stock. This rule would discriminate against banks as custodians for small shareholders. ${ }^{5}$ Small shareholders would then either let their votes go unexercised, travel to the annual meeting, or transfer their voting rights to other agents such as the D eutsche Schutzvereinigung für Wertpapierbesitz e.V., an organization dedicated to protecting small shareholders' rights «ttp://www. das-wertpapier.de/dsw/index.htm>.

\section{Internal Control Systems: \\ The Two-Tier Board System}

German stock corporations operate with a two-tier board system, in contrast to the single board specified in the corporate law of Anglo-Saxon countries. The Aufsichtsrat, or supervisory board (board of directors), consists of shareholder representatives and worker representatives in fixed proportions. Its members are non-executive directors (in contrast to U.S. practice, in which executives often dominate the board of directors), although the chairman is often a former CEO. The supervisory board typically meets two to four times a year to oversee the second-tier Vorstand, or management board, a committee composed of the firm's top executives.

Shareholder representatives on the supervisory board are normally elected at the annual meeting for a maximum term of five years. In some cases, however, blockholders have the right to appoint supervisory board members directly. Reappointments are permissible for both supervisory and management boards.

German supervisory boards are influenced strongly by worker representatives (employees and labor union executives), who are guaranteed seats by codetermination laws. Table 2 illustrates the board composition of the 100 largest firms in Germany. The number of board seats held by private banks has been declining in recent years, partly in response to public criticism of "excessive accumulation of power" by banks through board representation in excess of their direct ownership of stock. It should be noted, however, that bankers are often nom-

\section{Table 2}

Composition of Supervisory Boards of the 100 Largest German Firms

\begin{tabular}{|c|c|c|c|c|}
\hline \multirow{2}{*}{$\begin{array}{l}\text { Occupation or Affiliation } \\
\text { of Board Member }\end{array}$} & \multicolumn{4}{|c|}{$\begin{array}{l}\text { Number of Board Seats } \\
\text { (percent of total seats) }\end{array}$} \\
\hline & 1986 & 1988 & 1992 & 1993 \\
\hline Employee of the firm & $\begin{array}{l}520 \\
(35)\end{array}$ & $\begin{array}{l}542 \\
(36)\end{array}$ & $\begin{array}{l}519 \\
(35)\end{array}$ & $\begin{array}{l}549 \\
(35)\end{array}$ \\
\hline Labor union executive & $\begin{array}{l}197 \\
(13)\end{array}$ & $\begin{array}{l}187 \\
(13)\end{array}$ & $\begin{array}{l}191 \\
(13)\end{array}$ & $\begin{array}{l}211 \\
(14)\end{array}$ \\
\hline $\begin{array}{l}\text { Active or retired executive of } \\
\text { another firm, other than a bank }\end{array}$ & $\begin{array}{l}368 \\
(25)\end{array}$ & $\begin{array}{l}385 \\
(26)\end{array}$ & $\begin{array}{l}385 \\
(26)\end{array}$ & $\begin{array}{l}427 \\
(27)\end{array}$ \\
\hline Executive of a private bank & $\begin{array}{c}114 \\
(8)\end{array}$ & $\begin{array}{c}104 \\
(7)\end{array}$ & $\begin{array}{c}103 \\
(7)\end{array}$ & $\begin{array}{l}99 \\
(6)\end{array}$ \\
\hline Executive of a non-private bank & $\begin{array}{l}51 \\
\text { (3) }\end{array}$ & $\begin{array}{l}57 \\
(4)\end{array}$ & $\begin{array}{l}49 \\
(3)\end{array}$ & $\begin{array}{l}53 \\
\text { (3) }\end{array}$ \\
\hline Practicing attorney & $\begin{array}{l}147 \\
(10)\end{array}$ & $\begin{array}{l}152 \\
(10)\end{array}$ & $\begin{array}{l}153 \\
(10)\end{array}$ & $\begin{array}{l}155 \\
(10)\end{array}$ \\
\hline Politician or civil servant & $\begin{array}{l}69 \\
(5)\end{array}$ & $\begin{array}{l}69 \\
(5)\end{array}$ & $\begin{array}{l}80 \\
(5)\end{array}$ & $\begin{array}{l}67 \\
(4)\end{array}$ \\
\hline Total board members & $\begin{array}{l}1,466 \\
(100)\end{array}$ & $\begin{array}{l}1,496 \\
(100)\end{array}$ & $\begin{array}{l}1,480 \\
(100)\end{array}$ & $\begin{array}{r}1,561 \\
(100)\end{array}$ \\
\hline
\end{tabular}

SOURCE: Bundesverband deutscher Banken <http:/ / www.bdb.de>

inated to serve on supervisory boards by the firms themselves.

The chairman of the management board functions as the firm's CEO. The supervisory board appoints the members of the management board for a term of up to five years. Major decisions of the management board typically require the supervisory board's approval.

\section{External Control Systems: \\ The Legal Environment}

No corporate governance system can function without legal protections of investors' property rights. More specifically, the rights to own and dispose of equity shares in a firm and to vote on corporate matters that may affect the value of an owner's investment are fundamental to a well-functioning capitalist economy.

Several aspects of the legal environment in Germany are inimical to shareholders' rights, reducing the effectiveness of external control mechanisms such as the stock
${ }^{5}$ This restriction does not affect proxy voting by bank executive directors (as individuals), who occasionally represent blockholders. 
${ }^{6}$ The Volkswagen AG voting restrictions differ from others subsequently adopted by German stock corporations. They were established by law (the Volkswagen Privatization Act of 1960), and they apply not only to votes based on equity positions but also to proxy votes. Thus there is an implied upper limit to the fraction of total voting stock a bank can represent at the annual meeting, including proxy votes from small shareholders.

${ }^{7}$ The two cases are Feldmühle Nobel AG (acquired by Stora Kopparberg Bergslags AB of Sweden) and Hoesch AG (acquired by Fried. Krupp $\mathrm{GmbH})$. Feldmühle had a 5 percent voting restriction, while the limit for Hoesch was 15 percent. For details on these cases see Franks and Mayer (1994). SchneiderLenné (1994, p. 301) notes that Continental AG's voting restriction hindered Pirelli and its allies in their quest to take over Continental in 1990. market. We focus on three characteristics: codetermination laws, voting restrictions, and the existence of shares with multiple votes. The common denominator in the latter two institutional features is a deviation from the one-share/one-vote principle that underlies the efficiency and legitimacy of corporate governance arrangements (Grossman and Hart, 1988; Harris and Raviv, 1988).

Codetermination laws are a critical aspect of the legal environment in Germany because they impinge on shareholders' basic rights to exercise voting control over the firm's assets. It is usually thought that those who bear the residual risks of a firm's performance- the equity owners- should be able to make the key decisions that contribute to those outcomes. Codetermination laws partially unbundle residual control rights from residual cashflow rights. They allow employees to influence corporate decision making in ways that may conflict with the interests of shareholders.

Voting restrictions in corporate charters constitute a second category of legal infringement of the property rights of shareholders in Germany. A voting restriction is a ceiling on the share of total votes that a blockholder is allowed to cast at the annual meeting, regardless of the investor's share of contributed capital. A typical limit is between 5 percent and 25 percent of the total votes outstanding. Any investor who holds a block larger than the ceiling amount effectively loses normal voting rights on the shares in excess of the ceiling. Of course, this means that the blockholder's stake provides less than one vote per share, on average, and all other shareholders correspondingly receive more than one vote per share.

The first voting restrictions were introduced by Germany's federal government in the course of privatizing Volkswagenwerk in 1960. Initially, blockholders were limited to 2 percent of the vote, but in 1970 the limit was raised to 20 percent. ${ }^{6}$ Voting restrictions enjoyed some popularity after the first oil price shock in the 1970s, when investors from the Middle East began acquiring blocks in German firms. A common fear at the time was that these foreign investors would take control of blue-chip firms. Presumably, this loss of domestic control would lead to some harm to the nation's vital interests. In recent years, the number of corporations with voting restrictions has decreased substantially. As of October 1997, only 9 out of 800 traded firms had voting restrictions of some kind (Hoppenstedt Aktienführer 1998, 1997). It should be noted that two of the recent hostile takeovers in Germany succeeded despite the presence of voting restrictions. $^{7}$

The third pertinent feature of the legal environment in Germany is the prevalence of shares with multiple votes (preferred voting stock). The stock corporation law does not allow the issuance of such shares today, but firms that have issued shares with multiple votes have not been forced to convert them into ordinary shares. Shares of preferred voting stock are not traded at the stock exchange. They are a way for large shareholders to retain control over the firm without increasing their investment when new shares are issued. As in the cases al ready discussed, preferred voting stock effectively deprives other investors of the voting power their shares would command in a one-share/one-vote regime.

A prominent example of shares with multiple votes is provided by Siemens AG, where the founding family recently held a 5.29 percent stake in the common stock but had a 100 percent stake in preferred voting stock (as of October 1996). This preferred voting stock gives the family holders six votes per share on issues specified in the charter. Thus, although the family owns only 6.94 percent of the capital, it controls 14.03 percent of the votes on these special issues (Hoppenstedt Aktienführer 1997, 1996).

Changes in the shareholder structure of another firm with multiple-vote shares illustrates the relatively large size of such stakes. RWE AG, the largest utility in Germany, converted its multiple voting stock into ordinary shares in accordance with a shareholder vote at its annual meeting on 
February 26, 1998. After years of haggling over this issue with the VkA (Verband der kommunalen RWE-Aktionäre, or "Association of Local and Regional Governmental RWE Shareholders"), the management of RWE finally succeeded in passing such a resolution at the annual meeting. VkA held all of the outstanding preferred voting stock, each share of which carried 20 votes. As a consequence, VkA held 30.2 percent of the share capital but controlled 59.5 percent of the votes. To compensate for the loss of voting power, VkA was given a one-time cash payment of DM 1.15 bn. This sum serves as a rough estimate of the value of the extra voting rights these owners previously enjoyed বhttp://www.rwe.de>.

\section{External Control Systems: The Stock Market}

The stock market disciplines a publicly traded firm's management by pricing the firm's overall performance. M oreover, it is where control of the firm is traded. In principle, the stock market auctions every firm's assets each day to the team of investors and managers that believes it can create the most value by using them.

Are there alternatives to the stock market as an external control mechanism? The product market (that is, how successful the firm is in selling its products and services) provides an important input for the stock market evaluation process rather than providing an efficient substitute for it. Its discipline of a firm, in the absence of other controls, is likely to be very slow in coming and quite disruptive-i.e., culminating in bankruptcy - when it does occur (Townsend, 1979; Gale and Hellwig, 1985; Jensen, 1993). Bankruptcy, in turn, leads to a shift of control from shareholders to bondholders, who may not be the best parties to run the firm (Aghion and Bolton, 1992).

This section describes several important features of the German stock market in terms of its ability to function as an external corporate control system. In particular, we discuss the historically limited scope of the stock market in Germany, the extent and nature of shareholder concentration, the scarcity of hostile takeovers, the role of the pay-as-you-go private pension system in retarding financial-market development, the role of mutual funds, and finally, the importance of cross shareholdings and pyramid ownership structures.

Role of the Stock Market. Stock markets have traditionally been of little importance as a corporate control mechanism in Germany. There were 682 stock-exchangetraded corporations in Germany at year-end 1955, with total market value equal to 12.5 percent of GNP (Deutsche Bundesbank, 1988). At the same time, there were 3,007 traded firms in the United States with market capitalization of nine percent of GNP (Securities and Exchange Commission, 1957, pp. 91, 244). By the end of 1995, there were 802 traded stock corporations in Germany, with total market value equal to 24 percent of GNP (Deutsche Börse AG, 1997b). In the United States, on the other hand, some 9,566 traded firms accounted for a market capitalization equivalent to 105 percent of GNP (Wall Street Journal, 1998, pp. 395-97; Board of Governors, 1998).

By way of contrast, assets held by the banking sector are relatively more significant in Germany than in the United States. The assets of the banking sector (not including the central bank) amounted to 297 percent of GDP in 1960 and 234 percent in 1996. The corresponding figures for the United States were 66 percent in 1960 and 78 percent in 1996.

Germany has eight stock exchanges, among which the Frankfurter Wertpapierbörse (Frankfurt Stock Exchange) is the largest, with about 75 percent of total turnover. It is the fifth-largest stock exchange in the world, following the $\mathrm{N}$ ew York Stock Exchange (NYSE), the U.S. NASDAQ (over-the-counter) market, and the London and Tokyo stock markets. In 1996, its trading volume amounted to 15 percent of the trading volume at the NYSE and 70 percent of the trading volume in Tokyo (Aktionskreis Finanzplatz e.V., 1997). There were 681 firms listed on 
German stock exchanges in 1996, together with 123 firms that trade over the counter only. In the United States, 2,172 firms were listed on the NYSE; 5,167 on the NASDAQ; and 688 on the American Exchange (Hoppenstedt Aktienführer 1998, 1997).

There are three main market segments at the Frankfurt stock exchange. The first segment (Amtlicher Handel) listed 517 domestic firms at the end of 1996, plus 219 international firms (Deutsche Börse AG, 1997a, p. 11). The listing requirements of the second market segment (Geregelter Markt) are less strict than those in the first segment. This market serves mainly as a "launching pad" for young firms. The third market segment is the over-the-counter market, where listing requirements are minimal. Finally, an innovative new trading arena was introduced in March 1997 (N euer Markt; see below).

A number of laws (F inanzmarktförderungsgesetze) have been passed in recent years to improve the competitiveness of Germany as a financial center in Europe (Finanzplatz Deutschland). A significant reform was the introduction of a new market segment called Neuer Markt at the Frankfurt stock exchange in March 1997. This new market is meant to attract small and medium-sized, innovative companies. Firms listed in this market must publish their financial statements in English, base their prospectuses on international standards, and accept a takeover code (Deutsche Börse AG, 1996). Another major reform was the introduction of Xetra, an electronic trading system, in the first market segment (Amtlicher Handel) at the Frankfurt stock exchange. This reform eliminated order books; transactions are now fully transparent to all market participants.

Germany currently has no mandatory takeover code except for firms listed on the $\mathrm{N}$ euer $\mathrm{M}$ arkt. Instead, the takeover code is a voluntary agreement outlining recommended practices. It was introduced in July 1995 and was amended and tightened in January 1998 (Bundesministerium der Finanzen, 1998). The revised voluntary takeover code had been signed by
61 percent of the DAX-100 firms as of February 2, 1998 (Frankfurter Allgemeine Zeitung, February 3,1998$).{ }^{8}$ It requires that a bidder make a tender offer for all outstanding shares of the target once a controlling block in the firm has been acquired. Control is defined as ownership of more than 50 percent of the voting stock or the ability to cast at least 75 percent of the votes at the annual meeting, which may require less than 75 percent of the total shares outstanding, since some shareholders do not vote. Block holdings are posted for public information at the official website of the Bundesaufsichtsamt für den Wertpapierhandel (the equivalent of the U.S. Securities and Exchange Commission), «tttp://www.bawe.de>.

The voluntary takeover code has met strong resistance from some companies. For example, BMW, Hoechst, and Volkswagen have refused to sign on because they believe a large shareholder should not be forced to bid for all of the firm's outstanding shares when the purpose of the block holding is to protect specific property rights associated with relation-specific investments.

Shareholder Concentration. One important feature of the German stock market is the preval ence of large blockholders- that is, individuals, families, or firms that hold a high percentage of the outstanding stock of a single traded firm. Blockholders provide a form of concentrated ownership that mitigates the free-rider problem often found in firms with many small shareholders, none of whom has strong incentives to monitor the management. An alternative to concentrated ownership is the presence of a delegated monitor who represents dispersed owners- for example, a universal bank armed with the power to vote small shareholders' stakes in proxy.

Since 1995, German law has required mandatory disclosure of shareholdings of more than 5 percent of the outstanding equity. Earlier estimates of block ownership (such as the Hoppenstedt Aktienführer) were reasonably accurate, however. ${ }^{9}$

Table 3, based on Hoppenstedt data as of 
September 30, 1993, as used in Gorton and Schmid (1998a), provides information on the identity of the largest blockholders in German firms.

Table 3 shows that only 9 out of 198 large German firms (4.5 percent) had no blockholders at all (that is, all shares were dispersed among small shareholders). Of the 189 firms with blockholders, 165 had at least one blockholder with a stake of 25 percent or more. Some 125 firms ( 63 percent of the sample) had a blockholder with at least 50 percent of the equity, and 61 firms (31 percent) had a blockholder with a share of at least 75 percent. This high level of shareholder concentration in Germany far exceeds that in the United States (Franks and Mayer, 1994, p. 7).10

As noted above, universal banks may also hold blocks, but they are relatively infrequent blockholders. In terms of the number of blocks held, individuals, families, and nonfinancial firms are all more important. Gorton and Schmid (1998a) found that only 39 of the 198 firms in their sample ( 20 percent) counted a bank among their blockholders, and the blocks were smaller than typical blocks. In only three firms did a bank hold a block of 50 percent or more. Table 4 provides details on the equity stakes held by the 10 largest private banks in all German corporations. The table shows that, while the number of firms in which banks hold equity positions has increased over the last decade, there has been a decline in the frequency with which these stakes give banks outright control or a blocking minority position. With respect to traded firms only, the bottom part of Table 4 shows that private banks' equity stakes have actually been falling in recent years (from 46 to 30). As was true for the set of corporations as a whole, banks' equity stakes in traded firms are increasingly those of a minority shareholder - when they exist at all.

Similar conclusions emerge when one looks at bank equity ownership patterns among all corporations (i.e., counting all shares owned in traded and nontraded incorporated firms). The 10 largest private banks held only 1.3 percent of the face

\begin{tabular}{|c|c|}
\hline \multicolumn{2}{|c|}{$\begin{array}{l}\text { Largest Blockholders in a } \\
\text { Sample of Large German Firms }\end{array}$} \\
\hline & Number of firms \\
\hline $\begin{array}{l}\text { Firms without any blockholder } \\
\text { Firms with a blockholder } \\
\text { Total }\end{array}$ & $\begin{array}{c}9 \\
189 \\
198\end{array}$ \\
\hline Type of largest blockholder & Number of blocks \\
\hline $\begin{array}{l}\text { Foreign government } \\
\text { Not-for-profit organization (Verein) } \\
\text { Domestic insuranance company } \\
\text { Domestic government } \\
\text { (including foundations) } \\
\text { Domestic bank } \\
\text { Foreign nonfinancial company } \\
\text { Family (induding trusts) } \\
\text { Domestic nonfinancial company } \\
\text { Total }\end{array}$ & $\begin{array}{c}1 \\
1 \\
2 \\
11 \\
16 \\
21 \\
43 \\
96 \\
200^{*}\end{array}$ \\
\hline
\end{tabular}

\begin{tabular}{|c|c|}
\hline $\begin{array}{l}\text { Size of largest block held } \\
\text { by domestic nonfinancial } \\
\text { company (fraction of voting } \\
\text { stock = x) }\end{array}$ & Number of blocks \\
\hline $\begin{array}{l}x<0.25 \\
0.25 \leq x \leq 0.5 \\
0.5<x \leq 0.75 \\
x>0.75 \\
\text { Total }\end{array}$ & $\begin{array}{c}4 \\
14 \\
32 \\
46 \\
96\end{array}$ \\
\hline
\end{tabular}

* Two firms had blockholders of equal size.

SOURCE: Gorton and Schmid (1998a, Table 3); Saling Aktienführer 1994, 1993

value of corporate equity in 1976, while in 1994, this number was a mere 0.4 percent (Bundesverband deutscher Banken $\triangleleft t t p: / / w w w . b d b . d e>) .11$ The decline in the number of blocks and the fraction of corporate equity held by banks may indicate that, as Germany moves to a more market-oriented system of corporate finance, the bank blockholders' ability to add value to the firms they (partly) own has diminished.

Hostile Takeovers. Only a few hostile takeovers have occurred in post-World War II Germany, and there has never been a management-led leveraged buyout (LBO). ${ }^{12}$ One reason for the relative inactivity of the market for corporate control in Germany is the unusually small number of listed firms in comparison to the size and vitality of its economy. However, two
${ }^{10}$ A survey of stockexchange-listed firms in the United States in 1984 found that only 20 percent of the firms had at least one non-officer who owned 10 percent of firm's stock; 13 percent of the firms were majorityowned ( see Holderness and Sheehan, 1988).

11 These numbers should be viewed skeptically, however, because they are the least comprehensive of three measures of equity: face value, book value, and market value. Face or par value is the stated value of the shares at issue. Book value includes face value plus paid-in surplus and retained earnings. Market value is the number of shares outstanding times the market price per share. The market value of a firm's equity is often the most meaningful concept of the value of a firm.

12 Franks and Mayer (1994) describe two successful hostile takeovers and the unsuccessful attempt of Pirelli, an Italian tire maker, to take over Continental AG. More recently, Hochtief AG, a construction company, secretly acquired a majority stake in Philipp Holzmann AG, a competitor. Hochtief and its advisor, Deutsche Bank, then petitioned the European Commission in April 1997 for permission to pool their equity stakes in order to carny out a full merger between Hochtief and Holzmann. The German antitrust agency (Bundeskartellamt), opposed the takeover. The European Commission declined in June 1997 to issue a ruling in the case, citing their lack of standing in the case (Die Welt, March 26, and June 4, 1997, and Gieskes, March 24, and June 4, 1997). 


\section{Table 4}

Equity Stakes Held by the 10 Largest Private Banks

\begin{tabular}{lcccc} 
& 1986 & 1989 & 1994 \\
\hline $\begin{array}{l}\text { Number of firms in which banks } \\
\text { hold equity stakes (includes all corporations) }\end{array}$ & 89 & 101 & 135 \\
& & Number of firms in which \\
Fraction of the firm's outstanding equity & & \multicolumn{3}{c}{ banks held this equity stake } \\
(percentage)
\end{tabular}

SOURCE: Bundesverband deutscher Banken <http:// www.bdb.de>.

other (not mutually exclusive) explanations have been suggested. First, takeovers by means of stock market transactions may be more costly in Germany. As noted earlier in connection with the recent takeover attempt of Thyssen by Krupp, worker resistance and public disapproval may raise the economic hurdle that any proposed takeover must clear. Transactions that are barely profitable on their own financial merits will not be undertaken if worker and public relations costs are too high. Worker representatives on the supervisory board may resist even friendly takeovers unless they are able to share in some of the gains. Anticipation of this kind of "rent-seeking behavior" necessarily decreases the number of transactions that will be attempted.

Second, control mechanisms other than stock market takeovers may be more effective in removing corporate inefficiency in
Germany. U niversal banks and other large investors may be able to execute restructurings and control transfers behind the scenes at lower cost than is possible on the stock market. Takeovers may create costs for many "stakeholders" in the affected firms, some of which are not taken into account by the parties who initiate the change in control (Shleifer and Summers, 1988).

Private Pension System. One factor that contributes to the underdevelopment of the German stock market is the rather undeveloped nature of the private pension system. M ost importantly, only about 50 percent of currently employed workers in western Germany will receive private pensions (Betriebsrente), and virtually no workers in eastern Germany can expect private pension benefits (Bayerische Staatskanzlei, 1995). Second, private pension payments typically represent a supplement of only about 10 percent to 30 percent on top of a typical retiree's pension from the state-run system. Finally, Germany's private pensions are overwhelmingly provided on a pay-asyou-go (PAYG) basis. While this financing principle applies to public old-age and disability insurance systems around the world, it also applies to corporate pensions in Germany (Schneider-Lenné, 1992). Instead of paying contributions for employees' pensions into a separate pension fund, German employers merely make provisions on their balance sheets. Only current pension obligations require current expenditures. Of course, this means that accrual of future pension liabilities provides a source of financing (cash flow) for current corporate activities.

In a fully funded pension system, on the other hand, increases in future pension liabilities must be matched with current cash outlays required to purchase pension assets, usually long-term financial assets like stocks and bonds. The PAYG nature of private pension provision in Germany therefore has two effects, both of which reduce the importance of markets for longterm financial assets: First, pension provisioning on the balance sheet reduces the demand for financial assets to fund 
pension-holders' accounts. Instead, pension holders receive unsecuritized claims on their employers. Second, the ability to finance current operations by increasing pension liabilities reduces firms' supply of long-term financial assets to the market. Consequently, a country like Germany with a PAYG private pension system will have a smaller capitalization of stock and bond markets, along with lower trading volumes.

Investment Funds. Another retarding factor in the German stock-market environment has been the late start of mutual fund investing, a convenient and low-cost way for households to accumulate longterm financial assets. As late as 1960, investment funds' stock holdings were essentially zero. By 1990, this figure had risen to 4.3 percent of stock market capitalization and it had increased further to 7.5 percent by 1995 (Hoppenstedt Aktienführer 1997, 1996, p. xxxvii). In the United States, mutual funds held 12.8 percent of corporate equity at the end of 1995 (Board of Governors, 1998). The fact that German mutual funds have grown so fast in recent years may indicate that German households are concerned that the staterun pension system will not be able to sustain the current level of pension payments. Of course, we cannot say for sure whether the growth of stock mutual funds means that households have increased their overall holdings of stock relative to other investments. Findings based on direct ownership data reveal that the fraction of domestic shares held by domestic households fell from 31.8 percent in 1960, to 16.9 in 1990, and further to 14.6 in 1995. Other shareholder categories are nonfinancial firms, financial firms, the public sector, and foreign investors (Hoppenstedt Aktienführer 1997, 1996, p. xxxvii). Since households are also the ultimate owners of corporate stock through indirect means, the fraction of stock directly or indirectly owned by households remains unknown. ${ }^{13}$

Cross Shareholdings. A cross shareholding is an equity position one firm holds in another firm. It is possible for a web of cross shareholdings to exist in which firm $A$ holds equity in firm $B$, which holds equity in firm $C$, which, in turn, holds an equity stake in firm $A$. It may be difficult or impossible for an outsider to make a takeover bid or even to acquire a significant stake in a firm that is enmeshed in this kind of complex cross shareholding arrangement.

The most significant cross shareholding structure in Germany is centered on Allianz $A G$, the holding company of Europe's largest insurance group. This network of cross shareholdings encompasses several other important financial firms, including Munich Re, the world's largest reinsurance company, and both Deutsche Bank and Dresdner Bank, two of the largest German banks. The most common size of the stakes held in this network are 5 percent, 10 percent, or 25 percent of the target's equity. Some cross shareholdings were eliminated recently as a result of the merger of Bayerische Vereinsbank and Bayerische Hypotheken-und Wechsel-Bank, each of which comprised nodes in the Munichbased network surrounding Allianz.

It is likely that more cross shareholdings will be eliminated in Germany (and in Europe as a whole) as the financial-services sector consolidates. It has long been said that one of the purposes of cross shareholdings was to prepare for and facilitate consolidation. This is particularly likely to be true in the case of cross-border cross shareholdings within Europe.

Pyramids. Pyramids are a particular form of interfirm shareholding arrangement in which firm $A$ holds a stake in firm B, which holds a stake in firm $C$. The distinguishing characteristic of a pyramid arrangement is that firm $A$ is attempting to exercise control over firm $\mathrm{C}$ while minimizing its financial investment in firm $\mathrm{C}$, either directly or indirectly. Hence, a broad base of assets is controlled by a narrow pinnacle of equity investment. For example, if firm A holds a stake of slightly more than 50 percent in firm $B$, which in turn owns slightly more than 50 percent of the votes in firm $C$, then firm A can effectively exercise control over firm $C$ with just over 25 percent indirect
${ }^{13}$ Lower reported stockholdings by households may simply reflect changes in firm organizational structures. For example, suppose there is initially only one stock corporation owned entirely by households, the equity of which is valued at DM 100. Now the firm creates a holding company - the purpose of which is to hold the equity in the operating company. Households receive all the shares in the new holding company, worth DM 100. The holding company's assets consist of a 100-percent share of the operating subsidiany's equity, also worth DM 100 in total. If both the holding company and the operating subsidiary are listed on the stock exchange, households' share of total stockholdings falls from 100 percent to 50 percent, even though nothing fundamental has changed. In fact, many of the largest firms have recently moved toward a holding company structure, including RWE AG <http: / / www.rwe.de> and Hoechst AG <http:/ / www.hoechst.com>. 
ownership of the voting stock of firm C. Without the pyramid structure involving firm $B$, control over firm $C$ would require firm $A$ to hold more than a 50 percent direct investment.

There have been numerous cases of pyramiding among German firms. Some are motivated by the desire to "disenfranchise" minority shareholders, but many appear to be attempts to deal efficiently with more legitimate governance problems, such as joint ventures or relationshipspecific investments. ${ }^{14}$

Joint ventures are sometimes organized as subsidiaries owned jointly by the parties to the venture. A joint-venture subsidiary may, in turn, create other joint ventures, which are also organized as subsidiaries. Minority shareholders may be invited to hold stakes in some of the subsidiaries not so that they may be expropriated by the majority or controlling firms, but in order to promote cooperation at least cost to the ultimate organizers.

Another reason for pyramid shareholdings involves relation-specific investments or commitments made by customers or suppliers. If agents transact repeatedly at one or more stages of production, a pyramid may emerge as a way for a firm to cement important input or output relationships. In the absence of investments in such relationships, one or more of the parties may be subject to a "holdup problem," a form of opportunism that reduces economic efficiency in the same way as taxation or other forms of anticipated but essentially arbitrary wealth expropriation. If pyramiding occurs primarily to prevent opportunistic behavior by one or more firms that interact repeatedly, one could liken it to vertical integration.

A case watched closely by German competition authorities involves RWE AG. Local and regional administrative bodies in the state of N orth Rhine-Westphalia held about 57 percent of the votes in RWE as of October 1997. Both RWE and these public bodies are engaged in large-scale construction projects on an ongoing basis. RWE owns a 56.1 percent stake in Hochtief AG, a construction firm (41.1 percent direct;
15 percent indirect). Furthermore, Hochtief holds a 24.9 direct stake in Philipp Holzmann AG, one of its few significant competitors, plus an option to buy another 10 percent stake held by Commerzbank AG (H oppenstedt Aktienführer 1998, 1997). The motivations for RWE and the local authorities to build this pyramid structure are not clear, nor are the competitive effects it may have in the construction industry.

\section{EFFECTS OF UNIVERSAL BANKING AND CODETER- MINATION ON CORPORATE GOVERNANCE AND PERFORMANCE}

We now turn to the empirical evidence concerning universal banking and codetermination as they affect corporate governance in Germany. As the previous section made clear, both internal and external control mechanisms are available for guiding and disciplining firms' managements. Germany's institutions of universal banking and codetermination both shape and are shaped by Germany's internal and external control environments. Hence, sorting out cause and effect in the highly interrelated and complex system of corporate governance in Germany (or any other country) is a formidable chal lenge.

Before beginning our review, it is worthwhile to point out that the available empirical evidence on corporate governance in Germany is far from complete. Only a few rigorous quantitative studies analyze the influence of universal banking or codetermination on the performance of German firms, and these few are sometimes handicapped by small or unrepresentative datasets. These shortcomings can be traced directly to the paucity of readily available data on German firms' financial structures. Relatively few firms are publicly traded, and those that are do not face the type of disclosure requirements that are common in the United States. The lack of empirical evidence may have convinced some observers that there is no hope of drawing solid conclusions regarding 
universal banks, codetermination, or any

of the other unique or controversial aspects of German corporate governance. We hope to dispel some of the skepticism that surrounds these issues by reviewing recent empirical work that begins to lay the foundation for reliable analysis.

\section{Universal Banking}

The first econometric analysis focusing on the influence of universal banks in Germany was conducted by Cable (1985). Subsequently, studies by Edwards and Fischer (1994), Franks and Mayer (1994), Kaplan (1994), Elston and Albach (1995), Schmid (1996a,b,c), Gorton and Schmid (1998b), and others appeared. Without exception, sample sizes in these studies are small by U.S. academic standards.

Universal Banks, Control Structures, and Firm Performance. In a pioneering study, Cable (1985) investigated the influence of universal banks on the performance of German firms by analyzing a sample of 48 traded German companies. His observations were chosen from a list of the 100 largest German companies in 1974. It is revealing to note that this list became available only because a government antitrust commission compiled the basic data and published its results (M onopolkommission, 1978). There had been no comprehensive publicly available source for even this rudimentary information previously.

Cable regressed financial performance on several characteristics of the firm's governance structure. He measured financial performance from accounting data averaged over the period 1968-72. Explanatory variables drawn from the firm's governance structure included the concentration of shareholdings among investors in the firm (measured by a Herfindahl index) and the fraction of votes exercised by banks at annual meetings in 1975, among others. Votes controlled by banks included both the shares they owned and the proxy votes they exercised for clients. The author also included several normalizing regressors, such as industry dummy variables.
Cable found that shareholder concentration and bank voting power had positive and significant influences on firm performance. In other words, the more concentrated the ownership among the firm's shareholdings and the larger the proportion of votes cast at annual meetings by banks, the better was a firm's financial performance. These findings appeared to provide strong support for universal banking as a means of enhancing the performance of German firms. Schmid (1996a,b) confirmed Cable's qual itative results while arguing that Cable's original methodology was suspect.

Cable's performance measure was flawed in two ways (Schmid, 1996a,b). First, his observations of firm performance were for a time period before the firm's control structure was observed, when, in fact, the causal hypothesis being tested- that a firm's control structure affects its performance- requires precisely the reverse ordering. Thus, Cable's findings cannot be used to rule out the alternative hypothesis that it is good performance of the firm that causes high levels of shareholder concentration and bank voting power. Second, Cable's performance measure is difficult to interpret. It is the ratio of net income to total assets, i.e. it relates equityholders' income to the capital provided by equityholders and debtholders. M ore appropriate measures of firm performance may be derived by dividing net income by (book value of) equity (yielding ROE, return on equity), or interest expense (income of debtholders) plus net income divided by total assets.

Gorton and Schmid (1998b) provided additional evidence that German firms' control structures are systematically related to their financial performance. Combining Cable's dataset with another compiled by Böhm (1992), Gorton and Schmid examined the relationship between several indicators of a firm's control structure and three different performance measures: ROE, ROA (return on assets), and the marketto-book ratio of equity (MTB). Using 82 observations from 1975 and 56 observations from 1986, Gorton and Schmid found that bank equity positions and shareholder 
concentration measures, in general, were positively related to firm performance and statistically significant. Although the statistical significance of the relationship was not strong in every regression, the coefficients were never significantly negative.

For example, the null hypothesis that bank proxy voting makes no difference to firm performance could not be rejected in any of the specifications. On the other hand, Gorton and Schmid (1998b) found that direct ownership of shares by banks was significantly and positively related to measures of market value. In particular, a 1-percentage-point increase in the fraction of a firm's shares held by banks was associated with an increase in the market value of the firm's equity of between 0.60 percent and 0.86 percent.

Gorton and Schmid (1998b) used their dataset to investigate several other hypotheses concerning universal banking and corporate governance. They found no evidence of a change in the relationship between bank-dominated control structures and firm performance between 1975 and 1986. They also found no evidence to indicate that universal banks exploit any conflicts of interest that may exist in carrying out their roles as lenders, shareholders, and custodians (proxy voters) of small shareholders' shares.

To test for conflicts of interest, Gorton and Schmid (1998b) checked for nonlinearities in the impact of shareholder concentration, the banks' equity holdings, and proxy voting on firm performance. The presence of such nonlinearities could indicate a conflict of interest for banks in their roles as equityholders and custodians of small shareholders' votes. Under the conflict-of-interest hypothesis, the way banks use proxy votes depends on how much equity they own in the firm in question. N onbank blockholders may alter but not eliminate the bank's conflict of interest, so there will be another nonlinearity in the relationship. On the basis of Gorton and Schmid's results, one cannot reject the hypothesis of no conflict of interest.

In a related study, Edwards and Fischer (1994) concluded that German banks do not use the proxy votes they control to install their own representatives on supervisory boards. The authors reasoned from these results that banks do not act in the interests of small shareholders and therefore are subject to a conflict of interest. However, Franks and Mayer (1994) and Gorton and Schmid (1998b) provided evidence contrary to the findings of Edwards and Fischer (1994); that is, they found that ownership does translate into supervisory board representation. Banks do not appear to interfere with shareholder representation according to actual ownership.

How Do Universal Banks Affect Firm Performance? The bulk of the evidence reviewed suggests that universal bank involvement has a positive effect on firm performance; Edwards and Fischer (1994) is the exception. These studies are very crude in one sense, however: They merely test for a statistical relationship, rather than providing much economic insight into what is taking place. A slightly different approach to the general question of the relationship between universal banking and firm performance is to look for specific mechanisms or channels through which universal banks may improve (or hinder) performance.

One strand of the corporate finance literature suggests that banking relationships may improve firm performance because so-called "internal" capital markets reduce the information asymmetry between borrowers and lenders. They also buffer firms from shocks that reduce the efficiency of financial intermediation in "external" (public) markets. Using evidence from Japan, one study, Hoshi, Kashyap, and Scharfstein (1990), concluded that "main-bank" relationships reduce firms' costs of financial distress.

Elston and Albach (1995) reported that evidence for Germany pointed to reduced liquidity constraints when strong banking relationships were present. They compared a group of 29 firms that had significant bank ownership stakes in 1991 to another group of 92 firms that did not 
have a bank blockholder in the same year. The authors examined the periods 196772, 1973-82, and 1983-92, finding no liquidity constraints (defined as no correlation between internally generated cash flow and investment expenditures) in the first two subperiods for either group of firms. Finding a positive relationship in the latest subperiod only for firms without a bank blockholder, they concluded that firms with close bank ties have better access to financial capital.

One should be cautious in interpreting Elston and Albach's results, however. First, authors such as Kaplan and Zingales (1997) have called into question some of the critical identifying assumptions used in the literature on the cash-flow sensitivity of investment, of which Elston and Albach is a part. Even proponents of this stream of research, such as Hubbard (1998), admit that there is a serious problem in using average $\mathrm{Q}$ (market-to-book ratio of a firm's assets) instead of marginal q, to measure the firm's marginal incentive to invest. Unfortunately, Elston and Albach use the less appropriate average Q. Second, Elston and Albach make the unrealistic assumption that the firms' shareholder structures were invariant over the 25 -year period they analyzed. In other words, ownership structures were assumed to be completely constant over time. Finally, they erroneously classified one industrial company as a bank, contaminating their bankownership data. ${ }^{15}$

Is It Universal Banking or Relationship Banking that Matters? A natural question to ask is whether the positive influence on firm performance associated with a banking relationship requires banks to operate as universal banks. Couldn't a strictly commercial banking relationship ease liquidity constraints just as well? In fact, the traditional German Hausbank (house-bank) relationship is based on commercial- rather than investmentbanking activities (Fischer, 1990; Elsas and Krahnen, 1998).

Schmid (1996c) argued that universal banking enhances firm performance above and beyond what commercial and investment banking can do separately. Using data for all 62 German stock corporations for which he could identify a bank blockholder at the end of 1990, Schmid found that the average firm's ROE displayed a Ushaped pattern when plotted against the level of banks' equity holdings. Underlying this pattern, Schmid found that a firm's interest rate on debt was monotonically increasing in bank equity holdings.

The logic of Schmid's (1996c) argument is that universal banks are able to price commercial- and investmentbanking services jointly, a strategy that is not feasible when such banks provide their individual services independently. Crosssubsidization may be beneficial in this context because of a free-rider problem among shareholders. Generally, an individual shareholder bears the full cost of monitoring his investment, but he receives its benefit only in proportion to his ownership stake. This disparity drives a wedge between the optimal level of monitoring from the perspective of individual shareholders and the socially optimal level. As a result, monitoring intensity is too low from a social planner's point of view. ${ }^{16}$

A bank that owns a small block will use an increase in voting power (associated with increased ownership) to divert earnings away from equity. As the bank's block becomes larger, however, the bank stands to earn a higher fraction of the net (after interest) income created by its active monitoring of a firm's management. This is why, at high levels of ownership, the bank's incentive to divert earnings away from equity declines with further increases in the size of the block. Taken together, these considerations lead one to expect a U-shaped relationship between a firm's ROE and the level of bank equity ownership.

The bank has an incentive to translate higher voting power into higher interest rates on bank debt because increasing the firm's interest burden increases the firm's tax shield. One would therefore expect a monotonically increasing interest rate as a function of bank equity ownership. ${ }^{17} \mathrm{How}$ ever, banks cannot increase the firm's

\footnotetext{
${ }^{15}$ Apparently misled by its name, the authors classified Holderbank Financière Glaris Ltd. as a bank. In fact, Holderbank is a cement group. Its name is taken from the town of Holderbank, located in the Swiss canton of Aargau, where the company was founded in 1912 <http:/ / www. holderbank.com>.

${ }^{16}$ Given that the marginal return on corporate control is decreasing and the marginal costs are non-decreasing, the actual level of monitoring exerted by the bank will be too low from the standpoint of maximizing the wealth of all shareholders.
${ }^{17}$ This relationship is consistent with a U-shaped relationship between ROE and bank equity ownership because the total return on assets is a weighted sum of the interest rate on debt and the return to equity. The weights are the fractions of debt and equity in total assets, respectively. These weights may adjust as the size of the bank's block changes.


interest payments arbitrarily because competition from other banks limits the interest rate that the bank blockholder can impose on the firm.

Germany's large universal banks have long been accused of "overcharging" for loans (Hilferding, 1910). M odern corporate governance theory provides more subtle and benign explanations of this phenomenon (for example, Rajan, 1992). The higher price that universal banks charge on loans may be an efficient mechanism for internalizing the benefits they create, but cannot capture, in their function as a delegated monitor for small shareholders.

The empirical evidence reviewed in this section provides some insight into the method and effectiveness of universal banking as a component of the German corporate governance system. However, these results are of limited use for crosscountry comparisons because the importance and interrelationships of individual corporate control features vary across different financial systems. Therefore, the conclusions one may draw from studies of corporate governance in Germany do not necessarily apply to the United States or to any other country.

\section{Codetermination}

${ }^{18}$ Kraft (1989) reviews earlier work that was flawed by unreliable datasets and inappropriate empirical methods.

${ }^{19}$ If $\beta$ is the regression coefficient in a semi-logarithmic model, then the percentage change of the dependent variable as a result of a switch of the dummy variable from zero to one is given by $100\left(e^{\beta}-1\right)$ (Halvorsen and Palmquist, 1980). Using the regression coefficients displayed in Table 2 of FitzRoy and Kraft (1993), the 19.7 percent reduction in value added can be calculated as follows:

$\left(e^{0.13}-1\right)-\left(e^{-0.06}-1\right)$ $=0.197$.
The first rigorous empirical research investigating the effects of codetermination on firm performance was FitzRoy and Kraft (1993). ${ }^{18}$ Gorton and Schmid (1998a) and Schmid and Seger (1998) provided additional evidence on this topic.

Codetermination and Firm Performance. FitzRoy and Kraft (1993) examined the impact of the 1976 Codetermination Law on the productivity of 68 big German companies. Their sample was chosen to include firms that were required by the new law to increase from one third to one half the fraction of supervisory board seats occupied by worker representatives. FitzRoy and K raft (1993) estimated a translog production function to measure firm productivity in both 1975 and 1983. The authors reasoned that these years represented the pre- and post-legislation environments and similar stages of the business cycle.

FitzRoy and Kraft (1993) estimated that the introduction of equal representation by workers on supervisory boards reduced the 'value added' of the affected firms by 19.7 percent. ${ }^{19}$ Moreover, the authors concluded that the average firm's ROE declined by 5 percentage points as a result of the legislation. This is a substantial reduction, given that the sample mean of ROE equaled only 9.3 percent in 1975.

Schmid and Seger (1998) analyzed a sample of 160 large traded stock corporations observed in 1975, 1986, and 1990. The study exploited publicly available information on bank proxy voting (as in Gorton and Schmid, 1998b) and obtained 64 observations by collecting the attendance lists from annual meetings. As did Cable, Schmid and Seger regressed a financial performance measure- the market-to-book ratio of equity (MTB) - on proxies for ownership and control characteristics as well as normalizing regressors such as firm size and industry dummy variables. As in FitzRoy and Kraft (1993), Schmid and Seger compared firms with equal representation to firms with one-third representation of workers on the supervisory board. In contrast to FitzRoy and Kraft, Schmid and Seger did not compare the pre- and post-legislation performance of a given firm but instead pooled their observations and used year dummies and firm-specific control variables to isolate the effects of codetermination.

Schmid and Seger (1998) measured the impact of codetermination by examining the regression coefficient on a dummy variable that took a value of one if the firm had more than 2,000 workers, and was therefore subject to the new law, or zero if the firm had fewer than 2,000 workers and was not affected. The results suggest that equal representation caused an 18 percent decrease in share prices. In other words, shareholders are willing to give up around 22 percent of the current value of their pre-legislation investment to abrogate the Codetermination Law of 1976. This will- 
ingness to pay can be viewed as the market price of the loss of control rights suffered by shareholders.

Why Does Codetermination Affect Firm Performance? Whereas Schmid and Seger (1998) estimated only how codetermination affected the market value of corporate control, Gorton and Schmid (1998a) investigated the underlying causes and ultimate consequences of codetermination in detail. Using a pooled time-series crosssection approach covering the 250 largest traded stock corporations during the 198993 period, the authors confirmed that equal representation by workers on the supervisory board was associated with a negative impact on the firm's MTB, ROE, and ROA. The market value loss due to the introduction of equal board representation by workers was 12.2 percent (a bit lower than Schmid and Seger's (1998) estimate, which was based on a smaller sample in different years).

Gorton and Schmid (1998a) also analyzed the compensation structures of the management board and the supervisory board. Earlier work by Kaplan (1994) had suggested that shareholders were just about as active in controlling German firms as they were in the United States. Comparing 42 German firms with 146 U.S. and 119 Japanese companies over the period 198189 , Kaplan found that firm performance and executive turnover were negatively related in all three countries (i.e., worse performance is associated with higher executive turnover). Building on these results, Gorton and Schmid showed that the compensation of both management board members and supervisory board members in German firms is related positively to firm performance, just as it is in the United States. Furthermore, this payfor-performance relationship is robust to changes in the underlying measure of firm performance, encompassing ROA, ROE, and $\log$ of MTB. Gorton and Schmid estimated that a 1 percent increase in shareholder wealth raises the compensation of the management board by about 0.05 percent. $^{20}$
The positive link between firm performance and supervisory board compensation documented by Gorton and Schmid (1998a) is surprising because only a few German firms apply explicit performance-related compensation schemes for non-executive directors. As it turns out, however, compensation appears to be implicitly performancebased. Gorton and Schmid also found that the compensation scheme varies with the codetermination regime that applies to the firm. The pay of non-executive directors is more sensitive to firm performance when workers have equal board representation than when only one-third of the board is made up of worker representatives. Thus, it appears that shareholders provide stronger incentives for board members to act in shareholders' interests when workers are more heavily represented. Gorton and Schmid found that the pay of supervisory board members rises by 0.19 percent with a 1 percent increase in shareholder wealth when workers have less than equal representation, while the pay-for-performance elasticity is 0.34 when workers control one-half of the supervisory board seats.

\section{CONCLUSION}

The corporate governance systems in Germany and the United States entail both similarities and differences. Frequent changes in control over corporations or individual divisions have occurred in Germany, averaging some 1,500 per year since the late 1980s (Bundeskartellamt, 1997). Likewise, control changes are a frequent occurrence in the United States, with some 35,000 merger and acquisition events taking place during the $1976-90$ period (Jensen, 1993, p. 837).

However, the predominant methods by which control changes take place appear to differ in the two countries. Stock-marketbased control changes are frequent and sometimes contentious in the United States, while other forms of corporate control appear to operate in Germany. Large blockholders exist in the vast majority of German firms, exerting strong control over the management. Sales of large blocks of

\footnotetext{
${ }^{20}$ These findings are not directly comparable to the U.S. results presented by Jensen and Murphy (1990), because Jensen and Murphy used "first differences" instead of logarithmic values in their regressions. They found that CEO compensation changes by $\$ 3.25$ for every $\$ 1,000$ change in shareholder wealth.
} 
shares are common, although they are seldom carried out directly through the stock market. Universal banks are often able to exercise control in firms with dispersed ownership - that is, when no other blockholder exists, universal banks exploit the proxy voting authority granted to them by small shareholders.

Two distinctive features of the German corporate governance system are universal banking and codetermination. These institutional features are important for understanding the German system because they influence the ability of shareholders to exert control over the management of the firms they own. Relatively little empirical evidence is available for evaluating the effects of these institutions.

It is beyond the scope of this article to determine whether either the German or U.S. system of corporate governance is superior in any sense. Control changes brought about on stock markets or in the course of financial restructuring, as are common in the U nited States, appear to generate value for shareholders. For example, Jensen (1993, p. 837) estimates that shareholders in firms acquired over the period 1976-90 received gains of $\$ 750$ billion (expressed in terms of inflation-adjusted 1992 dollars). However, these control changes may have been costly for other "stakeholders" in the affected firms, including employees, communities, and bondholders (Shleifer and Summers, 1988).

More relevant to the German case, Jensen (1993, pp. 833-34) points out that the high level of activity in U.S. takeover markets-a mechanism for exercising corporate control that is external to the firmis evidence that internal control mechanisms have failed. The German corporate governance system is oriented more toward internal than external mechanisms. Large blockholders and universal banks are central to the functioning of internal control mechanisms. Thus, the lack of stockmarket-based takeover activity in Germany relative to the United States does not constitute evidence for or against either governance system. More research is needed to illuminate the underlying strengths and weaknesses of both systems of corporate governance.

\section{REFERENCES}
Aghion, Philippe, and Patrick Bolton. "An 'Incomplete Contracts' Approach to Financial Contracting," Review of Economic Studies (J uly 1992), pp. 473-94.

Aktionskreis Finanzplatz e.V. Finanzplatz Deutschland, Frankfurt a.M., 1997.

Allen, Franklin, and Douglas Gale. "A Welfare Comparison of Intermediaries and Financial Markets in Germany and the US," European Economic Review (February 1995), pp. 179-209.

Bayerische Staatskanzlei. "Bericht aus der Kabinettssitzung," September 18, 1995, <http:/ / www.bayern.de/ Politik/ Pressemitteilungen/ 1995MRat/ 09-18. html >.

Board of Governors of the Federal Reserve System. Flow of Funds Accounts of the United States: Flows and Outstandings, Fourth Quarter 1997, March 1998.

Böhm, Jürgen. Der Einfluß der Banken auf Großuntemehmen, Hamburg: Steuer und Witschaftsverlag, 1992.

Bundesaufsichtsamt für den Wertpapierhandel. "Erläuterung zu den Stimmrechtsanteilen," 1997, <http:/ / www. bawe.de/ ant_ erl.htm>.

Bundeskartellamt. "Bericht des Bundeskartellamtes über seine Tätigkeit in den Jahren 1995/ 96 sowie über die Lage und Entwicklung auf seinem Aufgabengebiet," 1997, <http:/ / www. bundeskartellamt. de/ kurztb.htm>.

Bundesministerium der Finanzen. "Übernahmekodex der Börsensachverständigenkommission beim Bundesministerium der Finanzen," January 1998.

Bundesverband deutscher Banken. "Datenbank für Wirtschaftsdaten," <http:/ / www.bdb.de/ daten/ zahlen/ Bankenlm.htm>.

Cable, John. "Capital Market Information and Industrial Performance: The Role of West German Banks," Economic Journal ( March 1985), pp. 118-32.

Deutsche Börse AG. Fact Book 1996, Frankfurt a.M., 1997a.

. . . . _ _ . . Germany as a Financial Center, Frankfurt a.M., $1997 \mathrm{~b}$.

Frankfurt a.M., 1996

Deutsche Bundesbank. 40 Jahre Deutsche Mark- Monetäre Statistiken 1948-1987, Frankfurt a.M.: Fritz Knapp, 1988.

Die Aktiengesellschaft. "Stimmen der Wirtschaft," Nr. 2 / 1974, p. 59.

Die Welt. "Holzmann-Poolvertrag in Sicht: Deutsche Bank und Hochtief bündeln Aktien- Kartellamt kritisch," March 26, 1997, p. 15.

"Elefanten-Hochzeit geplatzt: Hochtief und Deutsche Bank verzichten auf Beherrschung von Holzmann," June 4, 1997, p. 13. 


\section{REVIEW}

JUY / AUGUST 1998

"Countdown für neues Börsen-Zeitalter läuft: Start von Xetra steht nichts mehr im Wege- Makler und Regionalmärkte sehen sich als Verlierer," Nov. 25, 1997, p. 19

"Nikkei-Erholung läßt Dax weiter klettern: Börsenbarometer steigt auf 3954 Zähler- Varta klettern nach starkem Zwischenergebnis- Abschied von Ibis," Nov. 28, 1997, p. 20.

"Xetra erfolgreich gestartet: Neues Handelssystem löst lbis ab- 150 Millionen Mark investiert- Vorteile auch für Kleinanleger," Nov. 29, 1997, p. 18.

Dietl, Helmut M. Capital Markets and Corporate Governance in Japan, Germany and the United States, London: Routledge, 1998.

Edwards, Jeremy, and Klaus Fischer. Banks, Finance and Investment in Germany, Cambridge University Press, 1994.

Elsas, Ralf, and Jan Pieter Krahnen. "Is Relationship Lending Special? Evidence from Credit-File Data in Germany," Center for Financial Studies Working Paper, University of Frankfurt a.M., February 1998.

Elston, Julie A., and Horst Albach. "Bank Affiliations and Firm Capita Investment in Germany," ifo-Studien, (41(1), 1995), pp. 3-16

Financial Times. "European 500 Rankings," January 22, 1998 (special supplement)

Fischer, Klaus. Hausbankbeziehungen als Instrument der Bindung zwischen Banken und Untemehmen: Eine theoretische und empirische Analyse, doctoral thesis, University of Bonn, 1990.

FitzRoy, Felix R., and Komelius Kraft. "Economic Effects of Codetermination," Scandinavian Journal of Economics, (95(3), 1993), pp. 365-75.

Frankfurter Allgemeine Zeitung. "Von der Wildwest- Attacke zur friedlichen Fusionsverhandlung," March 18, 1998, p. 24. . "DSW: Übernahmekodex geht nicht weit genug," February 3,1998, p. 28

Franks, Julian, and Colin Mayer. "The Ownership and Control of German Corporations," The London Business School, unpublished manuscript, September 1994.

Gale, Douglas, and Martin Hellwig. "Incentive-Compatible Debt Contracts: The One-Period Problem," Review of Economic Studies (October 1985), pp. 647-63.

Gieskes, Hanna. "Bendenkliche Vision: Hochtief-Chef HansPeter Keitel hat sein Ziel erreicht," Die Welt, March 24, 1997, p. 16.

_. _ _ _ _ "Homberger Schießen," Die Welt, June 4, 1997, p. 14.

Gorton, Gary, and Frank A. Schmid. "Corporate Finance, Control Rights, and Fim Performance: A Study of German Codetermination," unpublished manuscript, The University of Pennsylvania, 1998a.

_. _._._. and _._._. . . "Universal Banking and the Performance of German Firms," unpublished manuscript, The University of Pennsylvania, 1998b.

Gottschalk, Amo. "Der Stimmrechtseinfluß der Banken in den Aktionärsversammlungen der Großunternehmen," WSI Mitteilungen (41(5), 1988), pp. 294-304.
Grossman, Sanford, and Oliver Hart. "One Share-One Vote and the Market for Corporate Control," Journal of Financial Economics (Jan./ Mar. 1988), pp. 175-202.

Halvorsen, Robert, and Raymond Palmquist. "The Interpretation of Dummy Variables in Semilogarithmic Equations," American Economic Review (June 1980), pp. 474-75.

Harris, Milton, and Artur Raviv. "Corporate Governance: Voting Rights and Majority Rules," Journal of Financial Economics (J an./ Mar. 1988), pp. 203-35

Hellwig, Martin. "Banking, Financial Intermediation and Corporate Finance (with discussion)," European Financial Integration, Albert Giovannini and Colin Mayer, eds., Cambridge University Press, 1991, pp. 35-72.

Hilferding, Rudolf. Das Finanzkapital: Eine Studie über die jüngste Entwicklung des Kapitalismus, Berlin, 1910.

Holderness, Clifford, and Dennis Sheehan. "The Role of Majority Shareholders in Publidy Held Corporations," Journal of Financial Economics (Jan./ Mar. 1988), pp. 317-46.

Hoppenstedt Aktienführer 1998. Verlag Hoppenstedt, ed., Darmstadt, November 1997.

Hoppenstedt Aktienführer 1997. Verlag Hoppenstedt, ed., Darmstadt, November 1996.

Hoshi, Takeo, Anil Kashyap, and David Scharfstein. "The Role of Banks in Reducing the Costs of Financial Distress in Japan," Journal of Financial Economics (September 1990), pp. 67-88.

Hubbard, R. Glenn. "Capital-Market Imperfections and Investment," Journal of Economic Literature (March 1998), pp.193-225.

Jensen, Michael C. "The Modem Industrial Revolution, Exit, and the Failure of Internal Control Systems," Journal of Finance (July 1993), pp. 831-80.

and Kevin J. Murphy. "Performance Pay and TopManagement Incentives," Journal of Political Economy (April 1990), pp. 225-64.

Kaplan, Steven N. "Top Executives, Turnover, and Fim Performance in Germany," Joumal of Law, Economics, and Organization (April 1994), pp. 142-59.

and Luigi Zingales. "Do Investment-Cash Flow Sensitivities Provide Useful Measures of Financing Constraints?" Quarterly Joumal of Economics (February 1997), pp. 169-215.

Kraft, Kornelius. "Empirical Studies on Codetermination: A Selective Survey and Research Design," Codetermination: A Discussion of Different Approaches, Hans G. Nutzinger, and Jürgen Backhaus, eds., Berlin: Springer-Verlag, 1989, pp. 277-98.

Manne, Henry G. "Mergers and the Market for Corporate Control," Journal of Political Economy (April 1965), pp. 110-20.

Monopolkommission. Hauptgutachten II (1976/ 77): Fortschreitende Konzentration bei Großunternehmen, Baden-Baden, 1978. 


\section{HivlEW \\ JULY / AUGUST 1998}

Rajan, Raghuram. "Insiders and Outsiders: The Choice between Informed and Arm's-ength Debt," Journal of Finance (September 1992), pp. 1367-400.

Saling Aktienführer 1994, ed. by Verlag Hoppenstedt, Darmstadt, November 1993

Schmid, Frank A. "Banken, Aktionärsstruktur und Unternehmenssteuerung (Teil I)," Kredit und Kapital (29(3), 1996a), pp. 402-27.

. "Banken, Aktionärsstruktur und Unternehmenssteuerung (Teil II)," Kredit und Kapital (29(4), 1996b), pp. 545-64.

"Beteiligungen deutscher Geschäftsbanken und Corporate Performance," Zeitschrift für Wirtschafts- und Sozialwissenschaften (116(2), 1996c), pp. 273-310. and Frank Seger. "Arbeitnehmermitbestimmung, Allokation von Entscheidungsrechten und Shareholder Value," Zeitschnift für Betriebswirtschaft (May 1998), pp. $453-73$.

Schneider-Lenné, Ellen R. "The Role of the German Capital Markets and the Universal Banks, Supervisory Boards, and Interlocking Directorships," Capital Markets and Corporate Governance, Nicholas Dimsdale and Martha Prevezer, eds., Clarendon Press, 1994, pp. 285-305.

. "Corporate Control in Germany," Oxford Review of Economic Policy (Autumn 1992), pp. 1-23.
Securities and Exchange Commission. $22^{\text {nd }}$ Annual Report, Washington, GPO, 1957

Shleifer, Andrei, and Robert W. Vishny. "A Survey of Corporate Governance," Journal of Finance, (June 1997), pp. 737-83. , and Lawrence H. Summers. "Breach of Trust in Hostile Takeovers (with discussion)," Corporate Takeovers: Causes and Consequences, Alan J. Auerbach, ed., University of Chicago Press, 1988, pp. 33-67.

Shonfield, Andrew. Modern Capitalism: The Changing Balance of Public and Private Power, Oxford University Press, 1965.

Townsend, Robert. "Optimal Contracts and Competitive Markets with Costly State Verification," Journal of Economic Theory (October 1979), pp. 265-93.

Wall Street Journal. Wall Street Joumal Almanac 1998, New York: Ballantine Books, 1997. 